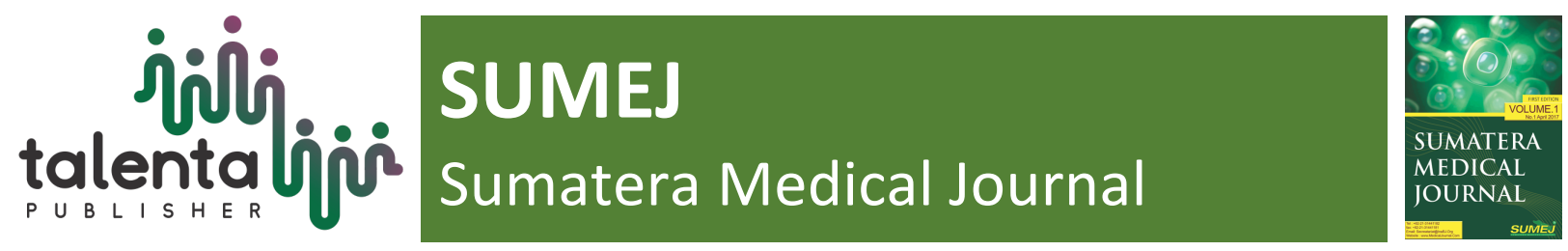

\title{
The Relationship of Knowledge, Attitude, and Behavior to Taking Care of External Genitalia with Leucorrhea Incident in The Darul Hikmah Islamic Boarding School Student
}

\author{
Khairina Zahra Triamanda Lubis ${ }^{*}$, Dwi Rita Anggraini ${ }^{2}$ \\ ${ }^{1}$ Student of Medical Faculty of Universitas Sumatera Utara \\ ${ }^{2}$ Anatomy Department Staff and Lecturer of Medicine Faculty of Universitas Sumatera Utara
}

\begin{abstract}
Introduction. The reproductive organ is a sensitive organ and requires special care. Leucorrhoea is often complained by young women as a reproductive health problem. Personal hygiene habits are an important factor to avoid infection. This is because the infection can cause vaginal discharge and cervical cancer. Indonesia, which has a tropical climate, causes about $90 \%$ of adolescent girls in Indonesia to have the potential to experience vaginal discharge which causes bacteria, fungi, and viruses to easily grow and develop so that the cases of vaginal discharge in young women in Indonesia are increasing. Objectives. To identify the relationship between knowledge, attitude, and behavior of taking care of external genitalia with vaginal discharge on students at Pondok Pesantren Modern Darul Hikmah. Methods. This is an analytical study with cross sectional design. The data was taken with primary data using questionnaires about knowledge, attitude, and behavior of taking care of external genitalia. Results. Leucorrhoea incidence rate at 103 respondents are 62 respondents (60.2\%) of normal vaginal discharge and 41 respondents (38.9\%) of abnormal vaginal discharge. Leucorrhoea incidence rates mostly happen to middle teenagers. There is a correlation between knowledge of taking care of external genitalia with vaginal discharge $(p=0.001)$. There is a correlation between attitude of taking care of external genitalia with vaginal discharge $(p=0.018)$. There is a correlation between behavior of taking care of external genitalia with vaginal discharge $(p=0.002)$. Conclusion. There is a correlation between knowledge, attitude, and behavior of taking care of external genitalia with vaginal discharge on students at Darul Hikmah Modern Islamic Boarding School.
\end{abstract}

Keyword: Vaginal discharge, Knowledge, Attitude, Behavior, Boarding school

Received date month year. | Revised date month year | Accepted date month year

\section{Introduction}

Reproductive organs are sensitive organs and require special care. Good knowledge and care are determining factors in maintaining reproductive health [13]. reproductive health is a state of

*Corresponding author at: [address of author's affiliation, city and country]

E-mail address: kazatril@yahoo.com 
complete physical, mental and social well-being that is not only free from disease or disability in matters relating to the reproductive system, its functions and processes [14].

Leucorrhoea is often complained by young women as a reproductive health problem. Leucorrhoea in adolescents needs special attention and if ignored will cause serious illness. Leucorrhoea is a natural thing and occurs before menstruation. Whitish that is clear or clear in color, odorless, does not itch, and in an amount that is not excessive is called vaginal discharge that is still within normal limits. If the liquid changes to a yellowish color, smells, and is accompanied by itching, abnormal vaginal discharge has occurred [6].

Personal hygiene habits are an important factor to avoid infection. This is because the infection can cause vaginal discharge and cervical cancer. Each year, 1 in 1,000 population is estimated to have an incidence of cervical cancer. This can lead to death (Nduru, 2015) [7]. About 75\% of women in the world have experienced vaginal discharge. Meanwhile, women in Europe who experience vaginal discharge are $25 \%$. Indonesian women who experience vaginal discharge are around $75 \%$. This figure differs sharply from Europe because of the humid weather in Indonesia [10].

In a study conducted in Pekanbaru, the prevalence of vaginal discharge in SMK Kansai Pekanbaru adolescents found 46 people (61.3\%) had sufficient knowledge of vulvar hygiene, as many as 40 people $(53.3 \%)$ had negative attitudes and as many as 43 people $(57.3 \%)$ have bad vaginal discharge precautions [17]. Other research conducted in Medan also showed that the incidence of vaginal discharge at the Santo Thomas 2 Private High School in Medan was very high, $96 \%$ of respondents had experienced vaginal discharge and $89.5 \%$ of them had pathological leucorrhoea [16]. Another study conducted at the AL-Munawwir Islamic Boarding School in Yogyakarta showed that $52 \%$ of the students had bad personal hygiene habits and $75.5 \%$ of the students had pathological fluor albus [8].

Adolescents in Islamic boarding schools have bad behavior towards personal hygiene, reaching $68 \%$. These teenagers often use their roommates' equipment in turn, including towels, clothes, pants and toiletries [2]. Based on the above studies, it was found that the knowledge, attitudes and behavior of students in maintaining external genital hygiene were still poor and the incidence of vaginal discharge was still widely experienced. The reason the researchers conducted research at the Darul Hikmah Modern Islamic Boarding School was because students who lived in dormitories tended to have less direct guidance on how to maintain genital hygiene from their parents so that students get knowledge about genital hygiene from their friends and based on their experience alone. 


\section{Methods}

This research is descriptive analytic with cross sectional design. The sampling technique used the method total sampling. This study aims to determine the relationship between knowledge, attitudes, and behavior of maintaining external genital hygiene with the incidence of vaginal discharge in Darul Hikmah modern Islamic boarding school students. The population of this study includes all students in the pesantren. Sampling was carried out by the researchers themselves, by selecting students who met the inclusion criteria, namely all students of the Darul Hikmah Modern Islamic Boarding School Medan City, agreed to be research subjects and were known to their parents / guardians, and had experienced vaginal discharge. The questionnaires were distributed to 103 students of the Darul Hikmah Modern Islamic Boarding School.

Sampling was carried out in stages, in July-September 2019. The data used in this study were primary data and were collected using a questionnaire that had been tested for validity and reliability. Data processing used computerization, and data analysis was performed univariate and bivariate with chi-square test.

\section{Results}

Based on the results of the questionnaire, it was found that 103 respondents $(97 \%)$ had vaginal discharge with bad knowledge $41.7 \%$, bad attitude $10.7 \%$, and bad behavior $21.4 \%$. In addition, it was found that 3 respondents (3\%) did not experience vaginal discharge. Respondents with the highest age were in the middle adolescent age range with 55 respondents (53.4\%).

Table 1. Frequency Distribution

\begin{tabular}{lcc}
\hline Variable & $\mathbf{N = 1 0 3}$ & $\mathbf{\%}$ \\
\hline Leucorrhea & & \\
Yes & 103 & 97 \\
No & 3 & 3 \\
Age & 30 & 29,1 \\
$\quad$ Early Teenager & 55 & 53,4 \\
Middle Teenager & 18 & 17,5 \\
Late Teenager & & 58,3 \\
Knowledge & 60 & 41,7 \\
Good & 43 & 89,3 \\
Bad & & 10,7 \\
Attitude & 92 & 78,6 \\
Good & 11 & 21,4 \\
Bad & & \\
Behavior & 81 & \\
Good & 22 & \\
Bad & & \\
\hline
\end{tabular}

According to the chi square test, there is a relationship between taking care of external genitalia hygiene knowledge with leucorrhea incident $(\mathrm{p}=0,001)$. 
According to the chi square test, there is a relationship between taking care of external genitalia hygiene attitude with leucorrhea incident $(\mathrm{p}=0,018)$.

According to the chi square test, there is a relationship between taking care of external genitalia hygiene behavior with leucorrhea incident $(\mathrm{p}=0,002)$.

Table 2. The Relationship Between Independent Variable with Leucorrhea Incident

\begin{tabular}{|c|c|c|c|}
\hline \multirow{2}{*}{ Variable } & \multicolumn{2}{|c|}{ Leucorrhea } & \multirow{2}{*}{$\mathbf{P}$} \\
\hline & Normal & Abnormal & \\
\hline Knowledge & & & 0,001 \\
\hline Good & $\begin{array}{c}47 \\
(45,6 \%)\end{array}$ & $\begin{array}{c}15 \\
(14,5 \%)\end{array}$ & \\
\hline $\mathrm{Bad}$ & $\begin{array}{c}13 \\
(12,6 \%)\end{array}$ & $\begin{array}{c}28 \\
(27,3 \%)\end{array}$ & \\
\hline Attitude & & & 0,018 \\
\hline Good & $\begin{array}{c}59 \\
(57,2 \%)\end{array}$ & $\begin{array}{c}33 \\
(32,2 \%)\end{array}$ & \\
\hline $\mathrm{Bad}$ & $\begin{array}{c}3 \\
(2,9 \%)\end{array}$ & $\begin{array}{c}8 \\
(7,7 \%)\end{array}$ & \\
\hline Behavior & & & 0,002 \\
\hline Good & $\begin{array}{c}55 \\
(53,3 \%)\end{array}$ & $\begin{array}{c}26 \\
(25,2 \%)\end{array}$ & \\
\hline $\mathrm{Bad}$ & $\begin{array}{c}7 \\
(6,7 \%) \\
\end{array}$ & $\begin{array}{c}15 \\
(14,8 \%)\end{array}$ & \\
\hline
\end{tabular}

\section{Analysis}

Based on the results of the research conducted, it shows a relationship between knowledge of maintaining external genital hygiene with the incidence of vaginal discharge in Darul Hikmah Modern Islamic Boarding School students. These results are relevant to research by Pamaruntuan et al in SMA Negeri 4 Manado, there was a significant relationship between knowledge and the incidence of vaginal discharge $(p=0,000)$ [11]. The results of this study are also consistent with the research of Nduru (2015). which was held in Bagan Deli Village, Medan Belawan District which showed that women with poor knowledge level, 9 out of 14 people (64.3\%) had pathological vaginal discharge [7]. knowledge is something that can be known and is related to the teaching and learning process. Learning activities are influenced a lot from internal factors, such as motivation and external factors in the form of available information facilities, as well as socio-cultural conditions [6], learning activities are influenced by many things derived from internal factors such as motivation and external factors such as information facilities, as well as socio-cultural conditions [1].

Based on the results of the research conducted, it was shown that there was a relationship between the attitude of maintaining external genital hygiene with the incidence of vaginal discharge in Darul Hikmah Modern Islamic Boarding School students. These results are relevant to research by Sari at Pertiwi High School, it was found that out of 53 respondents who had bad attitudes, 50 people (94.3\%) had experienced vaginal discharge [15]. Results of other studies conducted by 
Hassan with statistics in the study obtained $p$-value $=0.001$ which indicates a significant relationship between the respondent's attitude and the incidence of vaginal discharge [4]. Attitude is the most important thing in social psychology to determine a person's behavior. Through adolescent attitudes towards vaginal discharge, it can determine real action in the form of healthy behavior towards handling and prevention in order to avoid abnormal vaginal discharge [15].

Based on the results of the research conducted, it shows a relationship between knowledge of maintaining external genital hygiene with the incidence of vaginal discharge in Darul Hikmah Modern Islamic Boarding School students. These results are relevant to the study by Rahmi et al. at SMA Negeri 1 Rumbio Jaya with the results of statistical tests obtained $p$ value $=0.041$, which means that there is a significant relationship between respondent behavior and the occurrence of vaginal discharge [12]. Another study by Hassan found that respondents who had bad behavior and experienced abnormal vaginal discharge were 13 people (81.3\%) [4]. Human behavior that affects health can be classified into two categories, namely, behavior that is intentionally manifested (conscious) and behavior that is deliberate or unintentionally harmful or unintentionally brings benefits to health, both for individuals who carry out these behaviors and society. On the other hand, there are behaviors that are intentional or unintentional to harm the health of both the individual who does it and the community [9].

\section{Conclusion}

Based on the results of the research that has been done, it can be concluded that the incidence of vaginal discharge is divided into normal vaginal discharge with 103 respondents (97\%) and abnormal vaginal discharge with 3 respondents (3\%). There is a relationship between knowledge and the incidence of vaginal discharge $(p=0.001)$. There is a relationship between attitude and the incidence of vaginal discharge $(\mathrm{p}=0.018)$. There is a relationship between behavior and the incidence of vaginal discharge $(\mathrm{p}=0.002)$. It is recommended that the pesantren be able to increase the level of education regarding reproductive health, this can be done through counseling, promotion, and counseling activities. Suggestions for future researchers to be able to develop this research with other factors that influence the incidence of vaginal discharge.

\section{REFERENCES}

[1] Agus, R. and Budiman 2013, Kapita Selekta Pengetahuan dan Sikap dalam Penelitian Kesehatan. Salemba Medika, Jakarta.

[2] Akmal, S. C., Semiarty, R. and Gayatri, G. 2013, Hubungan Personal Hygiene dengan Kejadian Skabies di Pondok Pendidikan Islam Darul Ulum, Pelarik Air Pecah, Kecamatan Koto Tengah Padang Tahun 2013. Jurnal Kesehatan Andalas, Padang.

[3] Ayuningtyas, D. N. 2011, Hubungan antara Pengetahuan dan Perilaku Menjaga Kebersihan Genitalia Eksterna dengan Kejadian Keputihan pada Siswi SMA Negeri 4 Semarang. Universitas Diponegoro. 
[4] Hassan, M. R. Bin 2015, Hubungan Perilaku Mengenai Keputihan dengan Riwayat Kejadian Keputihan pada Ibu-Ibu Nelayan di Kelurahan Bagan Deli Kecamatan Medan Marelan Tahun 2015.

[5] Herdalena, N. 2003, Pengetahuan dan Perilaku Seksual Remaja.

[6] Ilmiawati, H. and Kuntoro 2016, Pengetahuan Personal Hygiene Remaja Putri pada Kasus Keputihan. Jurnal Biometrika dan Kependudukan, Universitas Airlangga.

[7] Nduru, L. M. 2015, Hubungan Perilaku Mengenai Keputihan dengan Riwayat Kejadian Keputihan pada Ibu-Ibu Nelayan di Kelurahan Bagan Deli Kecamatan Medan Belawan. Universitas Sumatera Utara. doi: 10.1007/s13398-014-0173-7.2.

[8] Nikmah, U. S. and Widyasih, H. 2016, Personal Hygiene Habits dan Kejadian Flour Albus Patologis pada Santriwati PP AL-Munawwir, Yogyakarta. Jurnal MKMI, Yogyakarta.

[9] Notoatmodjo, S. 2012, Konsep Perilaku dan Perilaku Kesehatan. Dalam : Notoatmodjo S. Promosi Kesehatan dan Perilaku Kesehatan. PT Rineka Cipta, Jakarta.

[10] Octaviyanti, D. 2006, Departemen Obstetri dan Ginekologi FKUI/RSCM. Jakarta. Available at: http://library.usu.ac.id/download /fkm/ fkmsiti khadijah.pdf.

[11] Pamaruntuan, A. T. C., Ratag, B. T. and Rattu, J. A. M. 2015, Hubungan Antara Pengetahuan Tentang Keputihan dan Higiene Perorangan dengan Kejadian Keputihan Patologis pada Siswi Sekolah Menengah Atas Negeri 4 Manado. Universitas Sam Ratulangi Manado.

[12] Rahmi, E. Y., Arneliwati and Erwin, H. 2014, Faktor Perilaku yang Mempengaruhi Terjadinya Keputihan pada Remaja Putri.

[13] Ratna, D. 2010, Pentingnya Menjaga Organ Keperempuanan. Indeks, Jakarta.

[14] RISKESDAS 2010, Badan Penelitian dan Pengembangan Keseharan Kementerian Kesehatan Republik Indonesia. Jakarta.

[15] Sari, W. K. 2018, Identifikasi Faktor Penyebab Keputihan pada Remaja Putri. Universitas Adiwangsa Jambi.

[16] Tambak, H. S. P. 2014, Hubungan Perilaku Menjaga Kebersihan Genitalia dengan Kejadian Keputihan pada Siswi SMA Swasta Santo Thomas 2 Medan Tahun 2014.

[17] Zalni, R. I. 2018, Hubungan Pengetahuan dan Sikap Remaja Putri Tentang Vulva Hygiene dengan Tindakan Pencegahan Keputihan. Lembaga Penelitian dan Penerbitan Hasil Penelitian Ensiklopedia, Pekanbaru. 